\section{Comparing Insect Pollinator Visitation for Six Native Shrub Species and Their Cultivars}

\author{
Jacob G. Ricker, Jessica D. Lubell, and Mark H. Brand \\ Department of Plant Science and Landscape Architecture, University of \\ Connecticut, Storrs, CT 06269 \\ Additional index words. Andrenidae, Bombus, nativar
}

\begin{abstract}
Interest in native landscape plants to support pollinators has increased. Most native plants sold by nurseries are cultivars, and some consumer and conservation groups question the suitability of native cultivars to support pollinators. In 2017 and 2018, insect pollinator visitation was quantified for six native shrub species and one or more cultivars of each species (Aronia melanocarpa, A. melanocarpa 'UCONNAM012' Ground Hog $^{\circledR}$, A. melanocarpa 'UCONNAM165' Low Scape Mound ${ }^{\circledR}$, Clethra alnifolia, C. alnifolia 'Hummingbird', $C$. alnifolia 'Ruby Spice', Dasiphora fruticosa, $D$. fruticosa 'Goldfinger', D. fruticosa 'Pink Beauty', Hydrangea arborescens, H. arborescens 'Annabelle', Kalmia latifolia, K. latifolia 'Sarah', Physocarpus opulifolius, and $P$. opulifolius 'Monlo' Diabolo ${ }^{\circledR}$ ). Insects were identified into 12 categories (Apis mellifera, Bombus spp., Andrenidae, Halictidae, Megachilidae, other bees, Lepidoptera, Syrphidae, other flies, wasps, Coleoptera, and other insects). The number of inflorescences and insect visitation was similar for $C$. alnifolia and its cultivars, and the compact cultivar Hummingbird had the greatest floral density. A. melanocarpa had more total visitors of Andrenidae than both of its compact cultivars because it was larger and produced more inflorescences. Compact Aronia cultivars and the straight species were mostly similar for Andrenidae visitation when compared on a per-inflorescence basis. $D$. fruticosa had more visitors of Bombus spp. and Megachilidae than both of its cultivars. These insects may have been less attracted to 'Pink Beauty' because of its pink flower color and 'Goldfinger' because of its wider flowers, which result from it being a tetraploid. $H$. arborescens 'Annabelle' had one-third the number of Bombus spp. visitors as $\boldsymbol{H}$. arborescens because 'Annabelle' produces $>\mathbf{5 0 \%}$ fewer fertile florets. $P$. opulifolius 'Monlo' attracted more syrphids than $P$. opulifolius possibly because flowers contrasted more strongly with the reddish purple foliage of 'Monlo' than with the green foliage of the straight species. Insect visitation was similar for $K$. latifolia and $K$. latifolia 'Sarah'. Based on this work, we determined that native shrub cultivars are not universally less or more attractive to pollinators and must be evaluated on a case-by-case basis.
\end{abstract}

There is increased interest in using native shrubs for landscaping to support pollinators (Gagliardi and Brand, 2007; Tallamy, 2007). Nurseries producing landscape plants typically grow cultivars, which are selections with better performance and ornamental characteristics than is typical of straight species (Wilde et al., 2015). Native shrubs produced from seeds are less marketable to a broad base of consumers because of variable quality (Getz, 2015). Straight species of native shrubs are frequently less suitable for landscaping because many are naturally large in stature and consumers desire native shrubs that will fit their landscape and also support pollinators (Hansen, 2017). For this reason, nursery growers prefer to produce cultivars of native shrubs that maintain a compact habit. Native shrub cultivars have also been selected for having unique flower or foliage coloration or form compared with the straight species.

Received for publication 18 July 2019. Accepted for publication 20 Aug. 2019.

J.D.L. is the corresponding author. E-mail: jessica.lubell@ uconn.edu. habit, foliage color, flower color, or flower form. The objectives of this research were to determine if cultivars attracted the same number of insects as their species and to observe the diversity and quantity of different groups of insects.

\section{Materials and Methods}

Research planting. In 2015, a replicated research planting containing six native shrub species and one or two cultivars of each species for a total of 15 genotypes (Table 1) was established in a full sun field at the Plant Science Floriculture Greenhouse Facility in Storrs, CT (41.812643, -72.252741). The experimental unit was a single plant, and plants were arranged in a randomized complete block design with three replications ( 45 plants in total). Plants occupied five planting rows ( $16.5 \mathrm{~m}$ long and $1.2 \mathrm{~m}$ wide) with nine plants per row. Blocks were distributed over rows, and all did not have the same shape. Plants were spaced $1.8 \mathrm{~m}$ apart within rows, and rows were $1.2 \mathrm{~m}$ apart. Grass alleys between the rows were maintained by regular mowing. In 2015, a 3-m nylon-netted post fence was installed around the perimeter of the planting to exclude deer. Because of the observed damage from woodchucks and rabbits, an additional 1-m-tall wire mesh fence was installed in 2017 just outside the existing deer fence. Plants received supplemental irrigation at the rate of $2.7 \mathrm{~L}$ per plant per day in 2017 and 2018. Plants were fertilized in April and July of 2017 and 2018 with $30 \mathrm{~g}$ of granular $15 \mathrm{~N}-6.5 \mathrm{P}-12.5 \mathrm{~K}$ fertilizer (Loveland Products, Inc., Loveland, $\mathrm{CO}$ ). The soil at the research planting was a sandy loam, which had pH 5.3 and CEC $9.5 \mathrm{meq} / 100 \mathrm{~g}$.

Plant measurements. In 2017 and 2018, data were collected on plant height and width, number of inflorescences per plant (or flowers per plant for Dasiphora), inflorescence height and width, and number of flowers per inflorescence. Duration of flowering time was recorded in 2018. Plant height and width measurements were made in the end of June after leaf expansion. Plant width was measured twice, at right angles to each measurement, and averaged. Plant size was the product of height and two widths. Number of flowers per inflorescence and inflorescence height and width was measured for three representative inflorescences per plant and averaged. Inflorescence width was measured twice, at right angles to each measurement, and averaged. For D. fruticosa and P. opulifolius genotypes, the number of inflorescences was counted for a $25 \%$ quadrant of the plant, selected at random, and multiplied by four. Floral density was calculated by dividing the number of inflorescences per plant by the plant size.

Insect visitation. During the flowering period, insect visitation data were collected using visual observation. For each plant, insect visitation was quantified on 10 separate occasions, with each observation period lasting $5 \mathrm{~min}$. Observations were made during the optimal daily insect visitation time frame of 9:30 AM to 4:30 PM (Garbuzov and 
Ratnieks, 2014; Gillespie et al., 2017; Goulson and Darvill, 2004). Two observations, one in the morning and one in the afternoon, were made per plant per observation day. Observation days had temperatures above $17.8^{\circ} \mathrm{C}$, wind speeds of less than $13 \mathrm{~km}$ per hour, and mostly cloudless skies. Temperature and PAR light intensity at the research planting were monitored using a plant growth station (WatchDog 2475; Spectrum Technologies Inc., Aurora, IL). Insect observation was made $1 \mathrm{~m}$ away from the plant. Movement and noise were kept to a minimum during observation periods. An insect visit was defined as an insect landing or present on a flower. Insects were identified into 12 categories: A. mellifera, Bombus spp., Andrenidae, Halictidae, Megachilidae, other bees, Lepidoptera, Syrphidae, other flies, wasps, Coleoptera, and other insects. Insect counts taken during the 10 observation periods were summed for each plant. In 2016, plants of A. melanocarpa genotypes suffered heavy rabbit damage, and many shoots containing flower buds were lost, which prevented data collection in 2017. Following installation of additional fencing in 2017, A. melanocarpa plants recovered and produced many new shoots with flowers, and data on plant measurements and insect visitation were taken in 2018. Data were not taken on K. latifolia genotypes in 2017 because of the slow establishment of this species in the experimental planting.

Statistical analysis. Data from 2017 and 2018 were combined for statistical analysis, and the year was treated as a random effect. SAS software (version 9.4; SAS Institute, Cary, NC) was used for statistical analysis. Analysis of variance used the PROC GLIMMIX procedure, and mean separation was determined using Tukey's honestly significant difference test $(P \leq 0.05)$.

\section{Results and Discussion}

For A. melanocarpa and its cultivars UCONNAM165 and UCONNAM012, the primary pollinator visitors were bees from the family Andrenidae (Table 2). Additional important insect categories were other bees, other flies, and other insects. Significantly more andrenids visited $A$. melanocarpa than its cultivars UCONNAM165 and UCONNAM012. Hardin (1973) reported andrenids as potential pollinators of $A$. melanocarpa and observed ant (family: Formicidae) and fly visitors for this species. Flowers opened 5 to $7 \mathrm{~d}$ earlier for the $A$. melanocarpa cultivars than for the straight species (Fig. 1). Duration of bloom was 10 to $14 \mathrm{~d}$ for all three Aronia genotypes. As expected, A. melanocarpa was significantly (more than double) taller than both of its cultivars, and 'UCONNAM165' was taller than 'UCONNAM012' (Table 3). A. melanocarpa had significantly more inflorescences than 'UCONNAM165' and 'UCONNAM012'. To understand how the significant change in height between $A$. melanocarpa and 'UCONNAM012' affected pollinator visitation, for each plant we divided the number of andrenids by the number of inflorescences and compared the quotient, which was equivalent at 0.2 . This indicates that the compact cultivar UCONNAM012 does not appear to be less attractive to pollinators than $A$. melanocarpa, but its smaller size may limit the number of inflorescences and insect visits per plant. Garbuzov and Ratnieks (2014) observed bee preference for tall flowering Lavandula hybrid plants over their shorter flowering parental species, suggesting bees may gravitate toward inflorescences that are taller and, thus, more prominent.

A. melanocarpa 'UCONNAM012' is used in the landscape differently than the straight species $A$. melanocarpa. 'UCONNAM012' is normally used in large numbers of plants to develop a groundcover or mass planting, whereas the use of $A$. melanocarpa is typically limited to a small group or a single specimen planting because of its larger stature. A group of 12 'UCONNAM012' would occupy an area similar to that of four $A$. melanocarpa and have similar or greater pollinator visitation. 'UCONNAM012' had significantly more other insect visits than $A$. melanocarpa (Table 1). Other insects consisted of mostly ants, which are ground-dwelling insects that may have found it easier to access inflorescences on the shorter plants of 'UCONNAM012' and 'UCONNAM165' than the taller plants of $A$. melanocarpa.

There were no significant differences in insect visitation for all insect categories between $C$. alnifolia and its cultivars Hummingbird and Ruby Spice (Table 2). Change in the floral color from white $(C$. alnifolia and 'Hummingbird') to pink (C. alnifolia 'Ruby Spice') did not affect pollinator visitation. The flower color did not affect bee attraction for Lavandula species and cultivars, whose flower colors ranged from white to pink to blue (Garbuzov and Ratnieks, 2014). Most insects ( $\geq 80 \%$ ) for $C$. alnifolia and its cultivars were Bombus spp. (Table 2). Additional important insect categories were $A$. mellifera, other bees, Lepidoptera, and wasps. Bombus impatiens and $A$. mellifera were determined to be frequent visitors of $C$. alnifolia in a work conducted at the University of Connecticut by Hemingson (1986). In their assessment of bee visitation on woody ornamental landscape plants in Kentucky and southern Ohio, Mach and Potter (2018) found that for $C$. alnifolia 'Sixteen Candles', 39.6\% of bee visitors were of the species Bombus and $46.2 \%$ were halictids. The most abundant bee visitors for $C$. alnifolia 'Sixteen Candles' were members of Apidae (48.5\%).

As expected, C. alnifolia 'Hummingbird' was somewhat shorter and smaller in size than the straight species, $C$. alnifolia (Table 3). Despite its reduced stature, $C$. alnifolia 'Hummingbird' produced a similar number of inflorescences as $C$. alnifolia and C. alnifolia 'Ruby Spice'. Furthermore, $C$. alnifolia 'Hummingbird' had the greatest

Table 1. Nomenclature, flower color, plant habit, and source of study plants for six native shrub species and their cultivars.

\begin{tabular}{|c|c|c|c|}
\hline$\overline{\text { Genotype }}$ & Flower color & Plant habit & Source of plants \\
\hline Aronia melanocarpa & White & Upright & Wild collected, Nobleboro, MA \\
\hline A. melanocarpa 'UCONNAM165' & White & $\begin{array}{l}\text { Low-growing; } \\
\text { compact }\end{array}$ & $\begin{array}{l}\text { Mark Brand (Breeder), University of } \\
\text { Connecticut, Storrs, CT }\end{array}$ \\
\hline A. melanocarpa 'UCONNAM012' & White & $\begin{array}{l}\text { Low-growing; } \\
\text { prostrate }\end{array}$ & $\begin{array}{l}\text { Mark Brand (Breeder), University of } \\
\text { Connecticut, Storrs, CT }\end{array}$ \\
\hline Clethra alnifolia & White & Upright tall & Prides Corner Farms, Lebanon, CT \\
\hline C. alnifolia 'Hummingbird' & White & Compact & Prides Corner Farms, Lebanon, CT \\
\hline C. alnifolia 'Ruby Spice' & Pink & Upright tall & Prides Corner Farms, Lebanon, CT \\
\hline Dasiphora fruticosa & Yellow & Mounded; diploid & Wild collected, Montvale, CT \\
\hline D. fruticosa 'Goldfinger' & Yellow & Mounded; tetraploid & Prides Corner Farms, Lebanon, CT \\
\hline D. fruticosa 'Pink Beauty' & Pink & Mounded; diploid & Prides Corner Farms, Lebanon, CT \\
\hline Hydrangea arborescens & $\begin{array}{l}\text { White; few sterile } \\
\text { flowers }\end{array}$ & Broadly mounded & Prides Corner Farms, Lebanon, CT \\
\hline $\begin{array}{l}\text { H. arborescens } \\
\text { 'Annabelle' }\end{array}$ & $\begin{array}{l}\text { White; many sterile } \\
\text { flowers }\end{array}$ & Broadly mounded & Prides Corner Farms, Lebanon, CT \\
\hline Kalmia latifolia & White & Compact & $\begin{array}{l}\text { American Native Plants, Perry Hall, } \\
\text { MD }\end{array}$ \\
\hline K. latifolia 'Sarah' & Pink & Compact & Prides Corner Farms, Lebanon, CT \\
\hline Physocarpus opulifolius & White & $\begin{array}{l}\text { Upright spreading; } \\
\text { green foliage }\end{array}$ & $\begin{array}{l}\text { American Native Plants, Perry Hall, } \\
\text { MD }\end{array}$ \\
\hline P. opulifolius 'Monlo' & Pink & $\begin{array}{l}\text { Upright spreading; } \\
\text { purple foliage }\end{array}$ & Prides Corner Farms, Lebanon, CT \\
\hline
\end{tabular}




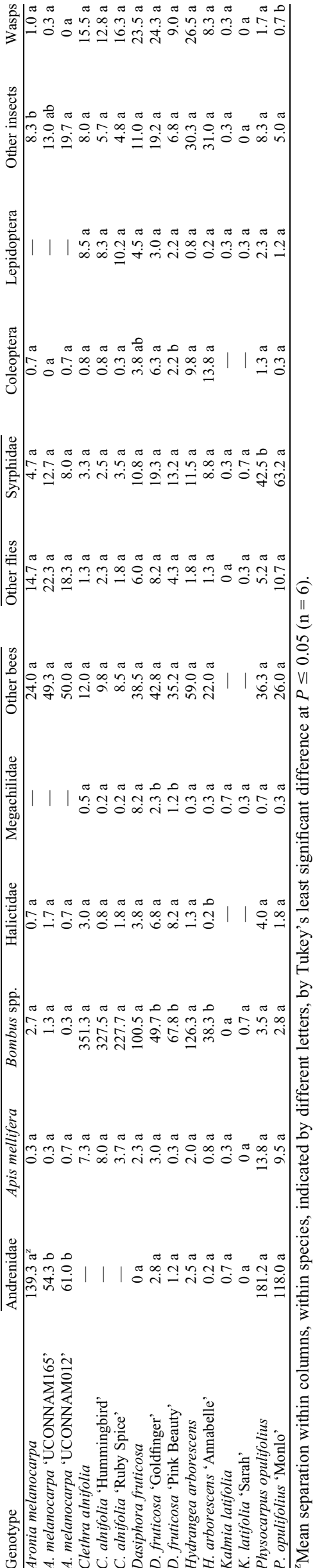

floral density. The bloom period for $C$. alnifolia and its cultivars lasted $14 \mathrm{~d}$ (Fig. 1). Flowers on $C$. alnifolia began opening $7 \mathrm{~d}$ earlier than they did for both $C$. alnifolia cultivars. These findings suggest that $C$. alnifolia and its cultivars, Hummingbird and Ruby Spice, do not vary in their ability to attract pollinators.

$D$. fruticosa had significantly more visitors of Bombus spp. and Megachilidae than both of its cultivars Goldfinger and Pink Beauty (Table 2). These insects were less attracted to $D$. fruticosa 'Goldfinger', possibly because 'Goldfinger' may be tetraploid, and changes to ploidy could affect pollinator visitation because of differences in floral resources or flower size (Segraves and Anneberg, 2016). We suspect that 'Goldfinger' is tetraploid because it originated from northern Europe (Holland), where tetraploid D. fruticosa is documented to exist (Elkington, 1969; Miller, 2002). In addition, D. fruticosa 'Goldfinger' had significantly wider flowers than D. fruticosa and D. fruticosa 'Pink Beauty' (Table 3), and increased flower size is evidence of tetraploidy (Segraves and Thompson, 1999). D. fruticosa 'Pink Beauty' and the $D$. fruticosa used in this study were derived from North American germplasm, which is diploid (Elkington, 1969; Lenz, 1997).

Bombus spp. and Megachilidae visitors may have been less attracted to $D$. fruticosa 'Pink Beauty' than the straight species because of its pink flower color. Several reports indicate that changes in flower color can influence pollinator visitation (Comba et al., 1999; Gumbert, 2000; White, 2016). By comparing eight herbaceous perennial species each with a cultivar possessing different flower color, six cultivars were visited less by some types of pollinators (White, 2016). For example, with Echinacea purpurea, bumblebees preferred the purple flowers of the straight species to the white flowers of the cultivar White Swan, but other insects did not demonstrate a preference (White, 2016).
Fewer coleopteran visitors were found on D. fruticosa 'Pink Beauty' than D. fruticosa 'Goldfinger' (Table 1) for two possible reasons: 1) these insects prefer yellow flower color rather than pink flower color (Gottsberger, 1977; Ollerton et al., 2009; Waser et al., 1996) and 2) these insects are attracted to larger flowers, which offer more physical support. After Bombus spp., the category other bees (Ceratina spp. and Hylaeus spp.) had the greatest number of visitors. In a Michigan State University evaluation of 43 northeastern U.S. native plants, $D$. fruticosa was one of only nine species distinguished as "highly attractive" to species of wild bees (Tuell et al., 2008). Denisow et al. (2013) studied the $D$. fruticosa cultivars Manley and Blink and found primarily Bombus spp., $A$. mellifera, and other solitary bee visitors. In our study, Megachile were observed harvesting flower petals on $D$. fruticosa and $D$. fruticosa 'Goldfinger', likely for use as a nesting material (Wilson and Carril, 2015).

$H$. arborescens had three times as many visitors of Bombus spp. as $H$. arborescens 'Annabelle' (Table 2). Other bees was an additional important insect category, which included Xylocopa virginica and Ceratina spp. H. arborescens and its cultivar Annabelle were of similar size and produced an equivalent number of inflorescences (Table 3). The onset of flowering occurred $7 \mathrm{~d}$ earlier for $H$. arborescens 'Annabelle' than $H$. arborescens (Fig. 1). Flowering duration was $28 \mathrm{~d}$ for $H$. arborescens 'Annabelle' and $21 \mathrm{~d}$ for $H$. arborescens. The inflorescence of $H$. arborescens is a lace cap, where sterile flowers form a ring around the perimeter of the inflorescence and the central flowers are fertile, containing pollen and nectar. $H$. arborescens 'Annabelle' was selected for having large inflorescences, composed of mostly sterile flowers, which are showier than the straight species (Dirr, 2009). As expected, plants of $H$. arborescens 'Annabelle' produced significantly wider inflorescences than $H$. arborescens (Table 3), with only $42 \%$ fertile flowers, which was

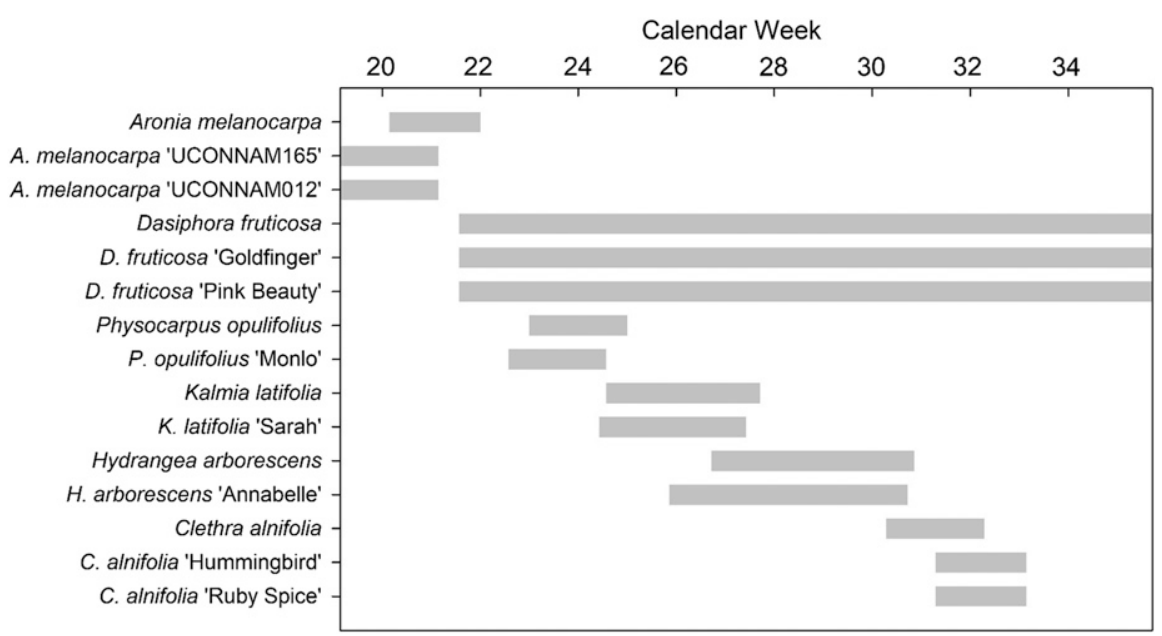

Fig. 1. Duration of bloom in 2018 for six native shrub species and their cultivars. 


\begin{tabular}{|c|c|c|c|c|c|c|c|c|}
\hline Genotype & $\begin{array}{c}\text { No. of } \\
\text { inflorescences } \\
\text { per plant }{ }^{\mathrm{z}}\end{array}$ & $\begin{array}{l}\text { Inflorescence } \\
\text { ht }(\mathrm{cm})\end{array}$ & $\begin{array}{c}\text { Inflorescence } \\
\text { width } \\
(\mathrm{cm})^{\mathrm{y}}\end{array}$ & $\begin{array}{c}\text { No. of } \\
\text { flowers } \\
\text { per in } \\
\text { florescence }\end{array}$ & $\begin{array}{c}\text { Plant } \\
\text { ht }(\mathrm{cm})\end{array}$ & $\begin{array}{l}\text { Plant } \\
\text { width } \\
(\mathrm{cm})^{\mathrm{x}}\end{array}$ & $\begin{array}{c}\text { Plant size } \\
\left(10,000 \mathrm{~cm}^{3}\right)^{\mathrm{w}}\end{array}$ & $\begin{array}{c}\text { Floral } \\
\text { density }^{\mathrm{v}}\end{array}$ \\
\hline Aronia melanocarpa & $691.3 \mathrm{a}^{\mathrm{u}}$ & $3.7 \mathrm{a}$ & $3.2 \mathrm{a}$ & $12.8 \mathrm{a}$ & $137.5 \mathrm{a}$ & $141.6 \mathrm{a}$ & $287.5 \mathrm{a}$ & $2.4 \mathrm{a}$ \\
\hline A. melanocarpa 'UCONNAM165' & $385.0 \mathrm{~b}$ & $3.3 \mathrm{a}$ & $3.5 \mathrm{a}$ & $14.6 \mathrm{a}$ & $65.9 \mathrm{~b}$ & $119.8 \mathrm{a}$ & $231.4 \mathrm{a}$ & $2.3 \mathrm{a}$ \\
\hline A. melanocarpa 'UCONNAM012' & $273.7 \mathrm{~b}$ & $3.5 \mathrm{a}$ & $3.5 \mathrm{a}$ & $14.9 \mathrm{a}$ & $43.1 \mathrm{c}$ & $127.7 \mathrm{a}$ & $178.7 \mathrm{a}$ & $1.3 \mathrm{a}$ \\
\hline Clethra alnifolia & $389.3 \mathrm{a}$ & $12.9 \mathrm{a}$ & $2.2 \mathrm{a}$ & $62.3 \mathrm{a}$ & $138.0 \mathrm{a}$ & $135.3 \mathrm{a}$ & $241.0 \mathrm{a}$ & $1.4 \mathrm{~b}$ \\
\hline C. alnifolia 'Hummingbird' & $382.3 \mathrm{a}$ & $13.5 \mathrm{a}$ & $2.8 \mathrm{a}$ & $59.7 \mathrm{a}$ & $91.2 \mathrm{~b}$ & $126.9 \mathrm{a}$ & $157.5 \mathrm{~b}$ & $2.4 \mathrm{a}$ \\
\hline C. alnifolia 'Ruby Spice' & $295.7 \mathrm{a}$ & $8.8 \mathrm{a}$ & $2.3 \mathrm{a}$ & $44.3 \mathrm{a}$ & $112.3 \mathrm{ab}$ & $134.6 \mathrm{a}$ & $209.8 \mathrm{ab}$ & $1.4 \mathrm{~b}$ \\
\hline Dasiphora fruticosa & $4125.3 \mathrm{a}$ & $1.9 \mathrm{a}$ & $2.6 \mathrm{~b}$ & - & $84.2 \mathrm{a}$ & $130.5 \mathrm{a}$ & $153.0 \mathrm{a}$ & $34.0 \mathrm{a}$ \\
\hline D. fruticosa 'Goldfinger' & $5304.7 \mathrm{a}$ & $1.5 \mathrm{a}$ & $3.0 \mathrm{a}$ & - & $78.8 \mathrm{a}$ & $129.4 \mathrm{a}$ & $140.6 \mathrm{a}$ & $53.0 \mathrm{a}$ \\
\hline D. fruticosa 'Pink Beauty' & $4360.0 \mathrm{a}$ & $1.4 \mathrm{a}$ & $2.5 \mathrm{~b}$ & - & $84.9 \mathrm{a}$ & $135.0 \mathrm{a}$ & $159.4 \mathrm{a}$ & $32.5 \mathrm{a}$ \\
\hline Hydrangea arborescens & $116.5 \mathrm{a}$ & $6.9 \mathrm{a}$ & $10.3 \mathrm{~b}$ & $644.9 \mathrm{a}$ & $134.5 \mathrm{a}$ & $176.4 \mathrm{a}$ & $441.5 \mathrm{a}$ & $0.3 \mathrm{a}$ \\
\hline H. arborescens 'Annabelle' & $118.3 \mathrm{a}$ & $7.4 \mathrm{a}$ & $15.0 \mathrm{a}$ & $746.0 \mathrm{a}$ & $99.4 \mathrm{a}$ & $126.7 \mathrm{a}$ & $167.1 \mathrm{a}$ & $0.7 \mathrm{a}$ \\
\hline Kalmia latifolia & $45.0 \mathrm{a}$ & $7.7 \mathrm{a}$ & $8.4 \mathrm{a}$ & $75.7 \mathrm{a}$ & $71.8 \mathrm{a}$ & $79.0 \mathrm{a}$ & $48.8 \mathrm{a}$ & $1.0 \mathrm{a}$ \\
\hline K. latifolia 'Sarah' & $22.0 \mathrm{a}$ & $6.2 \mathrm{a}$ & $6.4 \mathrm{a}$ & $75.3 \mathrm{a}$ & $74.1 \mathrm{a}$ & $89.8 \mathrm{a}$ & $75.2 \mathrm{a}$ & $0.4 \mathrm{a}$ \\
\hline Physocarpus opulifolius & $656.0 \mathrm{a}$ & $4.1 \mathrm{a}$ & $5.2 \mathrm{a}$ & $73.2 \mathrm{a}$ & $198.0 \mathrm{a}$ & $265.1 \mathrm{a}$ & $1449.6 \mathrm{a}$ & $0.5 \mathrm{a}$ \\
\hline P. opulifolius 'Monlo' & $702.7 \mathrm{a}$ & $3.5 \mathrm{a}$ & $4.7 \mathrm{a}$ & $48.0 \mathrm{a}$ & $191.2 \mathrm{a}$ & $246.5 \mathrm{a}$ & $1225.6 \mathrm{a}$ & $0.7 \mathrm{a}$ \\
\hline
\end{tabular}

${ }^{\mathrm{z}}$ Number of flowers for $D$. fruticosa, D. fruticosa 'Goldfinger', and D. fruticosa 'Pink Beauty'.

${ }^{\mathrm{y}}$ Inflorescence width was measured twice at right angles to each measurement and averaged.

${ }^{\mathrm{x}}$ Plant width was measured twice at right angles to each measurement and averaged.

${ }^{\text {w}}$ Plant size calculated using height and two perpendicular width measurements.

${ }^{v}$ Floral density was calculated by dividing number of inflorescences by plant size.

${ }^{\mathrm{u}}$ Mean separation within columns and within species and indicated by different letters, by Tukey's honestly significant difference at $P \leq 0.05$ ( $\mathrm{n}=6$ ).

significantly less than the $99 \%$ fertile flowers found for $H$. arborescens $(P=0.0008)$. Furthermore, fertile flowers on $H$. arborescens 'Annabelle' were positioned to the interior of the inflorescence and covered by sterile flowers, which may have impeded insect access to fertile flowers, especially for larger insects such as Bombus spp. Goulson (2003), and Heinrich (1979) noted that visitors of Bombus spp. pursue flowers with greater nectar and pollen resources, which may explain why $H$. arborescens had more Bombus spp. visitors than H. arborescens 'Annabelle'. An additional important insect category for Hydrangea was other insects, which included visitors of ants and ambush bugs (subfamily Phymatinae). Significantly more halictids were found for $H$. arborescens than its cultivar Annabelle, but this was a minor insect category for these plants (Table 2).

Overall, few insect visitors were observed for $K$. latifolia and its cultivar Sarah (Table 2). There were only two to three total insect visits over 10 observation events in 2018, during the 21-d bloom period (Fig. 1). The full sun study site was not optimal for Kalmia, which prefers shaded conditions. Plant foliage yellowed somewhat in the full sun and occasionally developed leaf spot disease. In the wild, plants inhabit bogs, barrens, and the edge of woods, swamps, and streams (Hightshoe, 1988). Plants grown in a partially shaded site may have had increased insect visitation. However, less insect visitation was found for $K$. latifolia growing naturally in a southern Appalachian heath bald (Real and Rathcke, 1991). Visitation rate averaged only 1.18 insect visits per 10 -min observation of 100 flowers. In our study, plants of $K$. latifolia and its cultivar Sarah were similar in size and produced 22 to 45 inflorescences per plant, with each inflorescence consisting of $\approx 75$ flowers (Table 3).
Andrenids were the most abundant visitors for P. opulifolius and its cultivar Monlo (Table 1). In their bee visitation study, Mach and Potter (2018) also found that the majority of visitors $(57.5 \%)$ for P. opulifolius were andrenids. We found that significantly more syrphids visited $P$. opulifolius 'Monlo' than $P$. opulifolius. Syrphidae species observed included Temnostoma spp., Toxomerus spp., and Eristalis spp. Plants of $P$. opulifolius and its cultivar Monlo were of the same size and produced a similar number of inflorescences (Table 3). P. opulifolius and 'Monlo' have similar leaf and flower forms, but $P$. opulifolius has green foliage and white flowers, and 'Monlo' has reddish purple foliage and flowers that are pink in bud that open to white. Syrphids are attracted to yellow and white flowers (Sajjad and Saeed, 2010; Shi et al., 2009), and for some flowers, olfactory cues are involved in attraction (Primante and Dötterl, 2010). In our study, syrphids may have been more strongly attracted to $P$. opulifolius 'Monlo' than the straight species because its white flowers contrasted more strongly against reddish purple foliage or there were olfactory cues provided by 'Monlo'. P. opulifolius had more wasp visitors than P. opulifolius 'Monlo', but wasps were a minor insect category for these plants.

The results of this study suggest that native shrub cultivars are not inherently less attractive to insect pollinators than the straight species. Similar conclusions can be drawn from the studies of Nevison (2016), Poythress and Affolter (2018) and White (2016) for native herbaceous perennial species and cultivars. This study and others identify examples of cultivars that were not as supportive of pollinators as the straight species, but also found examples of cultivars that are similarly, or more, attractive to pollinators than the straight species (Baisden et al., 2018; Nevison, 2016; Poythress and Affolter, 2018; White, 2016). Culti- var traits that can affect pollinator visitation may include conversion of anthers and pistils to petals, flower color, floral density, flower size, and possibly plant stature. When recommending plants for pollinator plantings, it is important to understand that whereas compact cultivars may attract fewer pollinators on a per-plant basis, on a landscape area basis, they may be comparable or better at attracting pollinators than the larger straight species form. Native shrub cultivars are not universally less or more attractive to insect pollinators and should be evaluated on a caseby-case basis.

\section{Literature Cited}

Baisden, E.C., D.W. Tallamy, D.L. Narango, and E. Boyle. 2018. Do cultivars of native plants support insect herbivores? HortTechnology 28:596-606.

Comba, L., S.A. Corbet, A. Barron, A. Bird, S. Collinge, N. Miyazaki, and M. Powell. 1999. Garden flowers: Insect visits and the floral reward of horticulturally-modifed variants. Ann. Bot. 83:73-86.

Denisow, B., S. Antoń, and G. Zymczak. 2013. The flowering, pollen production, and insect visitors in the ornamental shrub Potentilla fruti$\cos a$ L. (Rosaceae). J. Apic. Sci. 57:95-106.

Dirr, M.A. 2009. Manual of woody landscape plants. 6th ed. Stipes Publishing, Champaign, IL.

Elkington, T.T. 1969. Cytotaxonomic variation in Potentilla fruticosa L. New Phytol. 68:151160.

Gagliardi, J.A. and M.H. Brand. 2007. Connecticut nursery and landscape industry preferences for solutions to the sale and use of invasive plants. HortTechnology 17:39-45.

Garbuzov, M. and F.L. Ratnieks. 2014. Quantifying variation among garden plants in attractiveness to bees and other flower-visiting insects. Funct. Ecol. 28:364-374.

Getz, L. 2015. Landscape design goes native. Turf Mag. 12 June 2019. <https://www.turfmagazine. com/landscape-designbuildinstallation/landscapedesign-goes-native/>. 
Gillespie, S.D., J. Bayley, and E. Elle. 2017. Native bumble bee (Hymenoptera: Apidae) pollinators vary in floral resource use across an invasion gradient. Can. Entomol. 149:204-213.

Gottsberger, G. 1977. Some aspects of beetle pollination in the evolution of flowering plants, p. 211-226. In: K. Kubitzki (ed.). Flowering plants. Plant systematics and evolution/ Entwicklungsgeschichte und Systematik der Pflanzen. vol. 1. Springer, Vienna, Austria.

Goulson, D. and B. Darvill. 2004. Niche overlap and diet breadth in bumblebees; are rare species more specialized in their choice of flowers? Apidologie 35:55-63.

Goulson, D. 2003. Bumblebees: Behaviour, ecology, and conservation. Oxford Univ. Press, New York, NY.

Gumbert, A. 2000. Color choices by bumble bee (Bombus terrestris): Innate preferences and generalization after learning. Behav. Ecol. Sociobiol. 48:36-43.

Hardin, J.W. 1973. The enigmatic chokeberries (Aronia, Rosaceae). Bul. Torrey Bot. 100:178184.

Hansen, J. 2017. Natives vs. nativars: The need for both. Nursery Mgt. 12 June 2019. < https://www.turf magazine.com/landscape-designbuildinstallation/ landscape-design-goes-native/>.

Heinrich, B. 1979. Bumblebee economics. Harvard Univ. Press, Cambridge, MA.

Hemingson, J.C. 1986. The pollination biology of Clethra alnifolia L. (Clethraceae). Univ. of Connecticut, Storrs, CT, MS Thesis.

Hightshoe, G.L. 1988. Native trees shrubs, and vines for urban and rural America. Wiley, New York, NY.
Lenz, L.M. 1997. Plant 9,874 Potentilla fruticosa plant named 'Pink Beauty'. 17 June 2019. $<$ https://patents.google.com/patent/USPP9874P/ en>.

Mach, B.M. and D.A. Potter. 2018. Quantifying bee assemblages and attractiveness of flowering woody landscape plants for urban pollinator conservation. PLoS One 13:e0208428.

Miller, M.D. 2002. Shrubby potentilla. Royal Hort. Soc. 8 Nov. 2018. <http://staging.rhs.org.uk/ plants/pdfs/plant-trials-and-awards/plant-bulletins/ potentilla.pdf $>$.

Nevison, K.A. 2016. Considering a role for native plant cultivars in ecological landscaping: And experiment evaluating insect preferences and nectar forage values of Phlox species vs. its cultivars. Univ. of Delaware, Newark, DE, MS Thesis.

Ollerton, J., R. Alarcón, N.M. Waser, M.V. Price, S. Watts, L. Cranmer, A. Hingston, C.I. Peter, and J. Rotenberry. 2009. A global test of the pollination syndrome hypothesis. Ann. Bot. 103:1471-1480.

Poythress, J.C. and J.M. Affolter. 2018. Ecological value of native plant cultivars versus wild-type native plants for promoting hemiptera diversity in suburban areas. Environ. Entomol. 74:890901.

Primante, C. and S. Dötterl. 2010. A syrphid fly uses olfactory cues to find a non-yellow flower. J. Chem. Ecol. 36:1207-1210.

Real, L.A. and B.J. Rathcke. 1991. Individual variation in nectar production and its effect on fitness in Kalmia latifolia. Ecology 72:149-155.

Sajjad, A. and S. Saeed. 2010. Floral host plant range of syrphid flies (Syrphidae: Diptera) under natural conditions in southern Punjab, Pakistan. Pak. J. Bot. 42:1187-1200.
Segraves, K.A. and T.J. Anneberg. 2016. Species interactions and plant polyploidy. Amer. J. Bot. 103:1326-1335.

Segraves, K.A. and J.N. Thompson. 1999. Plant polyploidy and pollination: Floral traits and insect visits to diploid and tetraploid $\mathrm{Heu}$ chera grossulariifolia. Evol. 53:11141127.

Shi, J., Y.B. Luo, P. Bernhardt, J.C. Ran, Z.J. Liu, and Q. Zhou. 2009. Pollination by deceit in Paphiopedilum barbigerum (Orchidaceae): A staminode exploits the innate colour preferences of hoverflies (Syrphidae). Plant Biol. 11:17-28.

Tallamy, D. 2007. Bringing nature home. Timber Press, Portland, ME.

Tuell, J.K., A.K. Fiedler, D. Landis, and R. Isaacs. 2008. Visitation by wild and managed bees (Hymenoptera: Apoidea) to eastern US native plants for use in conservation programs. Environ. Entomol. 37:707-718.

Waser, N.M., L. Chittka, M.V. Price, N.M. Williams, and J. Ollerton. 1996. Generalization in pollination systems, and why it matters. Ecology 77:10431060.

White, A. 2016. From nursery to nature: Evaluating native herbaceous flowering plants versus native cultivars for pollinator habitat restoration. Univ. of Vermont, Burlington, VT, MS Thesis.

Wilde, H.D., K.J.K. Gandhi, and G. Colson. 2015. State of the science and challenges of breeding landscape plants with ecological function. Hort. Res. 69:1-8.

Wilson, J.S. and O.J.M. Carril. 2015. The bees in your backyard: A guide to North America's bees. Princeton Univ. Press, Princeton, NJ. 